\title{
Implementation Of Health Protocol In Preventing The Spread Of The Covid 19 Virus
}

\author{
Rahmadhani Fitri ${ }^{1}$, Hendra Fahruddin Siregar ${ }^{2}$, Adi Sastra Pengalaman Tarigan ${ }^{3 *}$ \\ Lecture Architectur Tehnic Universitas Pembangunan Panca Budi Medan \\ Sumatera Utara Indonesia. \\ Email : adisastra@dosen.pancabudi.ac.id
}

\begin{abstract}
.
Covid-19 is a positive single strain RNA virus that infects the respiratory tract. This virus spreads quickly, the only way is to prevent it. As time progressed, the conditions of transmission became more widespread and took many victims, ranging from adults, teenagers to children. This virus can attack anyone, this virus can also attack children with special needs. Children with special needs are children with special characteristics that are different from children in general without always showing mental, emotional, or physical disabilities. One of them is mental retardation. The more widespread the spread of the COVID-19 virus, the application and knowledge of health protocols must also touch the mentally retarded. This obstacle will affect them to adjust to the implementation of health protocols every day and homework for SLB C Muzdalifah to provide a safe place for students. Prepare students and teaching units in the implementation of New Normal Education. And Educate students so that they apply health protocols at all times. The approach method used in this community service is socialization through posters of health protocols and placement of hand sanitizers. Information on preventing the spread of covid 19 through posters and placing hand sanitisers in the SLB C Muzdalifah area as a reminder and teaching regularity in implementing health protocols. This information is expected to become a habit in the New Normal.
\end{abstract}

Keywords: Covid 19, SLB C Muzdalifah, Anak Berkebutuhan Khusus (Children with special needs, Health Protocols, Poster

\section{INTRODUCTION}

Covid -19 is a new viral infection that infected 90,308 people as of March 2, 2020. The virus, which is a positive single strain RNA virus, infects the respiratory tract. This virus spreads quickly, the only way is to prevent it. This virus can attack anyone, this virus can also attack children with special needs (ABK). Children with special needs are children with special characteristics that are different from children in general without always showing mental, emotional, or physical disabilities. One of the crew members is mentally retarded. The more widespread the spread of the COVID-19 virus, the application and knowledge of health protocols (prokes) must also touch children with special needs (ABK), as stated in Permendiknas No. 70 of 2009 Article 3 paragraph (1) concerning inclusive education.

\section{METHODS}

The approach method used in this community service is socialization through posters and hand sanitizers that are placed in several areas of SLB C Muzdalifah. This 
Socialization in SLB C Muzdalifah, JL. Garu VI Gg. Merak No. 15 A Kelurahan Harjosari I Kecamatan Medan Amplas Kota Medan Sumatera Utara.

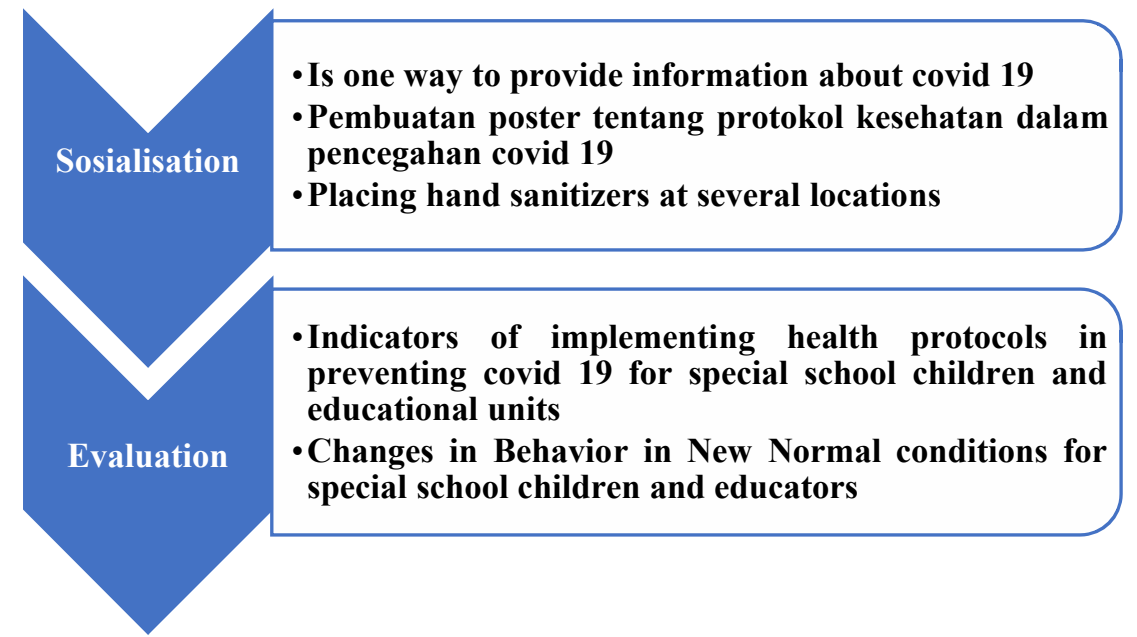

Fig1. Methode Diagram

\section{RESULT AND DISCUSSION}

SLB C Muzdalifah is one of the educational institutions for mentally retarded children. Learning at SLB C Muzdalifah is currently conducted online, where students are not present at school. However, teacher activities and activities continue despite restrictions on school attendance. The implementation of the Health protocol is carried out so that schools are ready to carry out New Normal Education.

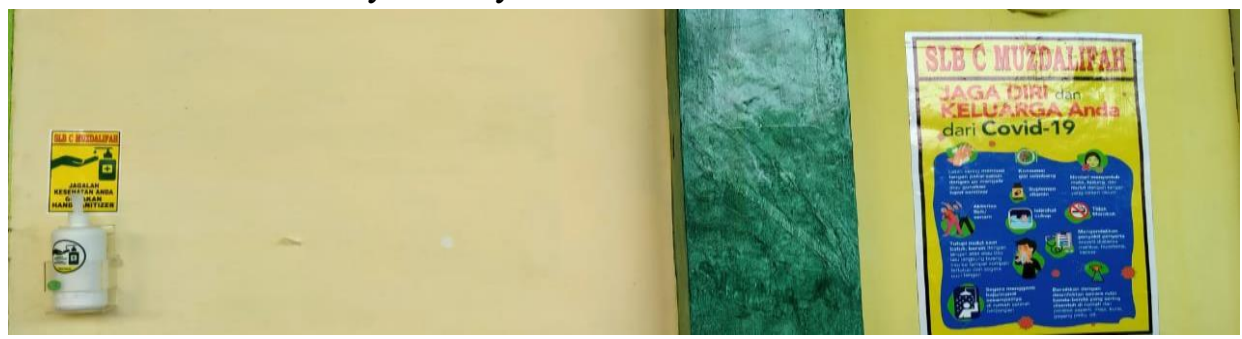

Fig 2. Hand Sanitizer and Health protocol poster.

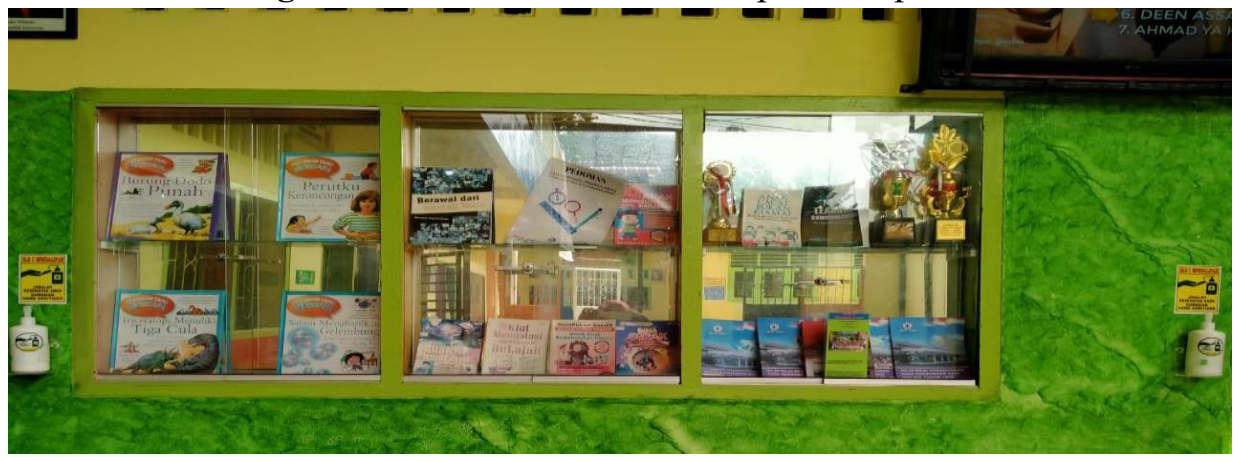

Fig 3. Position the Hand Sanitizer with the Wall Magazine. 
Health protocol information provided in the form of posters and stickers. The installation of posters and stickers is expected to raise awareness and remember the importance of readiness for New Normal Education, prevention of covid transmission and alertness in the attitude of preventing transmission of covid 19. Installation of Hand Sanitizer at every entrance provides information and awareness of maintaining cleanliness.

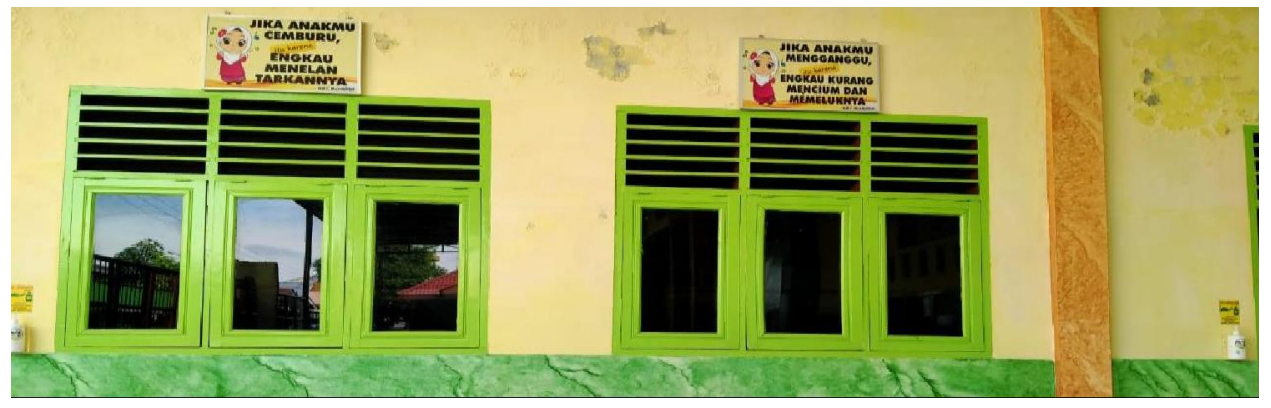

Fig 4. Placement of Hand Sanitizer near the entrance

The placement of posters and stickers is placed on:

1. Entrance (in line) SLB C Muzdalifah so that educators and students are ready to carry out education in the new normal period.
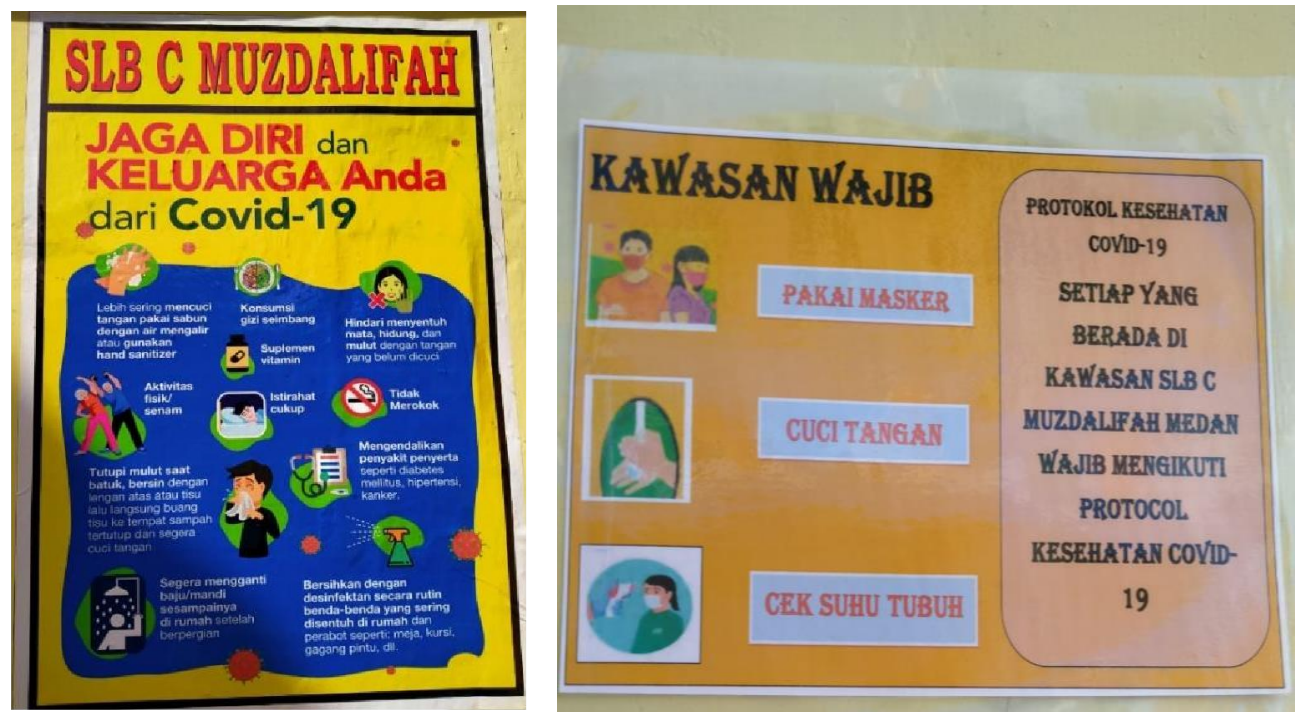

Fig 5. Health Protocol Poster

2. The exit door of SLB C Muzdalifah aims to make alertness in the attitude of preventing the transmission of covid able to be applied in every place and become a habit.

3. At every door, hand sanitizer is installed. 


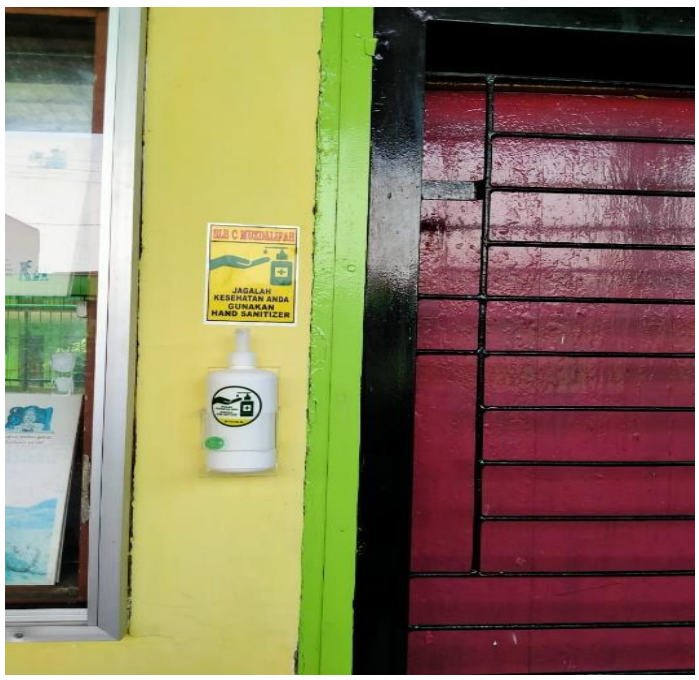

Fig 6. Hand Sanitizer Stickers

\section{Poster}

Poster is a publication media that combines writing, images, or a combination of both with the aim of providing information to the public. According to the Big Indonesian Dictionary (KBBI), posters are placards that are installed in public places which can be in the form of announcements or advertisements. Posters are usually installed in public places. bustling and strategic. Because of its inviting nature, it is very important to place the poster in an easily visible place. The selection of placing posters in crowded places looks like the entrance and exit of SLB C muzdalifah provides information that it is ready to deal with the prevention of covid -19. Giving posters that are placed exactly where the hand sanitiser is to remind and hasten to wash hands with hand sanitiser. The aims of the posters include:

1. Educational units become aware of how to prevent covid 19 being implemented.

2. The Education Unit becomes more prepared to face the New Normal Education.

3. Remind the public about what should be done.

4. Remind people to avoid things that harm themselves and others.

The placement of hand sanitisers is expected to prevent the spread of COVID19 , this is in accordance with the recommendations of the Health protocol and appeals from the government, one of which is washing hands regularly. Use soap and water, or an alcohol-based hand sanitizer.

\section{CONCLUSION}

Information on preventing the spread of covid 19 through posters and placing hand sanitisers in the SLB C Muzdalifah area as a reminder and teaching regularity in implementing health protocols. This information is expected to become a habit in the New Normal. 


\section{REFERENCES}

[1] Yuliana. 2020. Corona Virus diseases (covid-19); sebuah tinjauan literatur. Wellness and Healthy Magazine vol 2 No. 1 February 2020. P187-192. ISSN 2655-9951 (print), ISSN 2656-0062 (online)

[2] Melati Indah Oktafia PERAN POSTER SEBAGAI MEDIA EDUKASI COVID-19 DI MEDIA SOSIAL INSTAGRAM. Universitas Negeri Semarang

[3] Syaipudin, L. (2020). PERAN KOMUNIKASI MASSA DI TENGAH PANDEMI COVID-19 (Studi Kasus di Gugus Tugas Percepatan Penanganan Covid-19 Kabupaten Tulungagung). Kalijaga Journal Of Communication, 2, 15-16.

[4] Listina, O., Solikhati, D.I.K., \& Fatmah, I.S., (2020). EDUKASI CORONA VIRUS DESEASE 19 (COVID-19) MELALUI PENYEBARAN POSTER KEPADA MASYARAKAT KECAMATAN SLAWI KABUPATEN TEGAL. JABI: Jurnal Abdimas Bhakti Indonesia, Vol-1, No.2.

[5] Fitri Rahmadhani., Fahrudin Hendra Siregar, sastra Adi Tarigan. 2019. Penerapan Peduli Lingkungan Melalui kreatifitas Seni Anak Berkebutuhan Khusus dengan Konsep Tong Sampah Ceria. Fekon Press UNPAB. ISBN 978-623-90918-6-6

[6] Fitri Rahmadhani., Fahrudin Hendra Siregar, sastra Adi Tarigan. 2019. Peduli Lingkungan Bagi Anak Berkebutuhan Khusus dengan Penerapan Tong Sampah Ceria. Prosiding PKM CSR Vol 2 (2019) e-ISSN 2655-3570

[7] Fitri Rahmadhani., Fahrudin Hendra Siregar, sastra Adi Tarigan. 2019. Penerapan Arsitektur Prilaku dalam Tong Sampah Ceria Bagi Anak Berkebutuhan Khusu. Jurnal Nasional Teknik Sipil dan Arsitektur Vol 1, No. 1 (2019) 